DOI: https://doi.org/10.24867/11DS01Erdedi

\title{
ANALIZA POSTOJEĆEG STANJA I PREDLOG UNAPREĐENJA SISTEMA JAVNOG PREVOZA NA PODRUČJU SUBOTICE
}

\section{ANALYSIS OF THE EXISTING CONDITION AND PROPOSAL FOR IMPROVEMENT OF THE PUBLIC TRANSPORT SYSTEM IN SUBOTICA}

\author{
Čongor Erdedi, Fakultet tehničkih nauka, Novi Sad
}

\begin{abstract}
OBLAST - SAOBRAĆAJ I TRANSPORT
Kratak sadržaj - U ovom radu izvršena je detaljna analiza sistema javnog prevoza putnika u Subotici, i to sa aspekta organizacije $i$ angažovanih resursa. Opisane su mreže linija u oba podsistema, gradski $i$ prigradski podsistem, i ukazano je na određene nedostatnke istih. Predložene su $i$ sprovedene mere za poboljšanje $i$ unapređenje sistema javnog prevoza putnika u oba grada sa aspekta održivog transporta.
\end{abstract}

Ključne reči: Mreža linija, gradski $i$ prigradski podsistem, elektronski sistem naplate

Abstract - Detailed analysis of public transportation system of passangers in Subotica was executed. Description of line networks in the city is given and some disadvantages were pointed. Some measures were suggested and implemented for improvement of public transportation system of passengers in terms of sustainability in Subotica.

Keywords: Line network, urban and suburban subsystems, electronic billing system

\section{UVOD}

Sistem javnog gradskog i prigradskog transporta putnika $\mathrm{u}$ Subotici teži da se kontinuirano usmeri i pozicionira $\mathrm{u}$ skladu sa savremenim transportno-ekonomskim zahtevima rada sistema u cilju postizanja proizvodne i ekonomske efikasnosti i održivosti celine sistema.

Za uspešno ostvarenje ciljeva složenih organizaciono tehnološkog sistema, kao što je sistem javnog transporta putnika, neophodno je u određenim vremenskim presecima izvršiti proveru i unapređenje raznih elemenata.

$\mathrm{S}$ obzirom na probleme koji se javljaju kroz gradski transportni sistem, potrebno je sagledati različite strategije razvoja sistema javnog prevoza u zavisnosti od veličine gradova $[1,2]$.

Danas u svetu postoje dve osnovne strategije u pogledu razvoja gradova, i to "održivi razvoj" i "kvalitet života". Strategija "održivog razvoja" predviđa razvoj gradova koji će biti usklađen sa društvenim, ekonomskim i drugim mogućnostima.

\section{NAPOMENA:}

Ovaj rad proistekao je iz master rada čiji mentor je bio dr Milan Simeunović.
Sa aspekta javnog prevoza, strategija "kvaliteta života" podrazumeva omogućavanje mobilnosti stanovnika uz kontrolu upotrebe vozila.

Cilj rada jeste detaljna analiza sistema javnog prevoza putnika u Subotici koja se odnosi na oba podsistema, gradski i prigradski podsistem, kako bi se ukazalo na prednosti i nedostatke sistema javnog prevoza u gradu, a zatim predložile i sprovele mere za unapređenje i poboljšanje celog sistema sa aspekta održivog razvoja.

\subsection{Okruženje u kome funkcioniše sistem JMTP u Subotici}

Subotica se nalazi na samom severu Vojvodine, u neposrednoj blizini državne granice sa Republikom Mađarskom, što joj obezbeđuje karakteristiku gradskog naselja sa povoljnim geografskim položajem kao potencijalnim faktorom razvoja.

$\mathrm{Na}$ osnovu rezultata popisa sprovedenog u martu 2011. godine, gradsko naselje Subotica ima 107.726 stanovnika i zahvata površinu od 8245,10 hektara od čega je površina zemljišta unutar granice građevinskog rejona 8203,65 hektara, a površina zemljišta izvan granice građevinskog rejona 41,45 hektara, prema Generalnom urbanističkom planu grada Subotice.

Broj domaćinstava u 2011. godini iznosio je 40.290 domaćinstava, odnosno prosečna veličina domaćinstva na području Subotice je 2,67 stanovnika po domaćinstvu.

\subsection{Osnovni podaci o javnom preduzeću}

Javno preduzeće obavlja komunalnu delatnost, gradski i prigradski prevoz. Javno preduzeće je preduzeće koje obavlja delatnost od opšteg interesa, ako je osniva država, odnosno jedinica lokalne samouprave ili autonomna pokrajina. Organizovano je radi obavljanja delatnosti od opšteg interesa, kao i trajnog i nesmetanog obavljanja delatnosti, koja je nezamenljiv uslov života $\mathrm{i}$ rada radnih ljudi i građana.

Pretežna delatnost Javnog preduzeća jeste gradski i prigradski kopneni prevoz putnika (šifra 49.31), koju predstavljaju aktivnosti koje se odnose na obavljanje gradskog i prigradskog prevoza putnika autobusima, sa tačno utvrđenim redom vožnje na određenim relacijama $\mathrm{i}$ sa ukrcavanjem i iskrcavanjem putnika na određenim autobuskim stajalištima. 


\section{ANALIZA POSTOJEĆEG STANJA SISTEMA}

\subsection{Zakonski i regulatorni okviri}

Prvi korak analize sistema javnog prevoza jeste analiza zakonskih i regulatornih okvira i definisanje odgovornosti i obaveza gradskih organa uprave odgovornih za javni prevoz i prevoznika.

\subsection{Organizacija i upravljanje celinom sistema}

U postojećoj organizaciji, u funkcionalnom smislu, preduzeće se sastoji iz četiri sektora sa ukupno 313 zaposlenih (oko 3,44 zaposlena po inventarskom broju vozila, odnosno 3,91 zaposlena po operativno spremnom broju vozila). U okviru JP „SUBOTICA - TRANS” postoje tri nivoa upravljanja: strateški, taktički i operativni nivo.

\section{3. (MAKRO) analiza mreže linija}

Mreža linija koju opslužuje JP „Subotica - trans” se može, posmatrano u širem kontekstu, podeliti na dve celine. Prvu celinu čini mreža gradskih i prigradskih linija, odnosno mreža na kojoj se obavlja komunalna delatnost gradskog i prigradskog prevoza putnika.

Mreži linija prigradskog transporta dodate su i đačke prigradske linije. Drugu celinu čini mreža linija koja nije direktno vezana za komunalnu delatnost, i predstavlja privrednu delatnost javnog preduzeća kojom se obezbeđuje dodatni prihod. Ovu mrežu čine međumesne i međunarodne linije i linije na kojima se obavlja unapred ugovoreni prevoz radnika.

Transportnu mrežu sistema u Subotici čini 23 linije ukupne eksploatacione dužine od 741,4 kilometra posmatrano u oba smera, odnosno prosečne dužine od 394,3 kilometara. Posmatrano po strukturi linija, u sistemu ima 11 gradskih linija ukupne dužine od 217,8 kilometara posmatrano u oba smera, a prosečne dužine od 108,9 kilometara. Pored gradskih, mrežu čini i 12 prigradskih linija ukupne dužine od 523,6 kilometara posmatrano u oba smera, a prosečne dužine 285,4 kilometara.

\section{ANGAŽOVANI RESURSI}

\subsection{Transportni kapaciteti}

Struktura voznog parka u JP "SUBOTICA - TRANS" na dan 16.03.2020. bila je: 91 inventarsko vozilo, od čega 34 vozila u gradskom, 26 vozila u prigradskom i 31 vozilo u međumesnom transportu putnika.

Kada se posmatra struktura vozila prema tipu, najveću zastupljenost u okviru voznog parka u JP "SUBOTICA TRANS" imaju solo autobusi (dužine oko 12 metara), ukupno 53, što predstavlja $58,24 \%$ od ukupnog broja vozila.

Zglobnih autobusa (dužine oko 18 metara) u okviru voznog parka ima $15(16,48 \%)$. Broj minibusa u sistemu iznosi $8(8,79 \%)$, a midibusa $6(6,59 \%)$, s tim da su midibus vozila zastupljena samo $\mathrm{u}$ podsistemu međumesnog transporta putnika, dok su minibus vozila zastupljena u gradskom ( 7 vozila $)$ i prigradskom podsistemu transporta putnika (1 vozilo).

Struktura voznog parka prema markama i tipovima vozila je izrazito heterogena, odnosno postoji 10 različitih marki i 36 tipova vozila, što je na trenutnu veličinu voznog parka veoma nepovoljno.

Prosečna starost voznog parka u JP "SUBOTICA TRANS" na dan 16.03.2020. je iznosila 15,24 godine (15 godina i 3 meseca).

\subsection{Prosečna potrošnja}

U 2017. godini je ostvarena približna ukupna potrošnja pogonske energije po tipu vozila, koja je, u skladu sa tehnologijom funkcionisanja analiziranih tipova vozila, u opadajućem trendu posmatrano od gradskog ka međumesnom tipu vozila (gradski autobusi 665.556 litara, prigradski autobusi 619.897 litara, međumesni autobusi 1.943.428 litara). U 2018. godini je takođe ostvarena približno ista potrošnja pogonske energije po tipu vozila i najzastupljeniji su gradski autobusi u ukupnom učešću $(35 \%)$. Prosečna potrošnja pogonske energije izražena kroz potrošnju po vozilu litara/100 km u 2018. godini je veća u odnosnu na iste pokazatelje za 2017. godinu (2\%).

Ukupna prosečna godišnja potrošnja pogonske energije po vozilu u sistemu JP „SUBOTICA - TRANS“ ima približnu vrednost za obe analizirane godine, respektivno 2017. - 23.763,36 litara i 2018. - 23.628,17 litara.

\section{REZULTATI RADA}

\subsection{Broj prevezenih putnika}

Detaljnom analizom broja prevezenih putnika, odstupanje iznosi manje od $1 \%$. Ukupan broj prevezenih putnika u 2017. godini je iznosio 6.353.375, dok se u 2018. godini beleži blagi porast broja prevezenih putnika i iznosi 6.402 .629 putnika.

U 2017. godini najveće učešće u ukupnom broju prevezenih putnika ima gradski podsistem i iznosi $63,08 \%$, kao i u 2018 . godini $63,49 \%$. Gotovo identičnu zastupljenost i u 2017. i u 2018. godini u ukupnom broju prevezenih putnika ima prigradski podsistem i iznosi $27,41 \%$ i 27,31\%, respektivno, slika 1 . i slika 2.

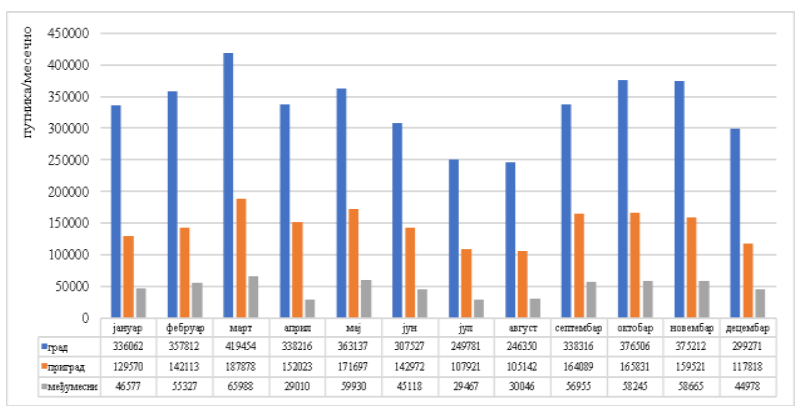

Slika 1. Broj prevezenih putnika po mesecima po podsistemima u 2017. godini 


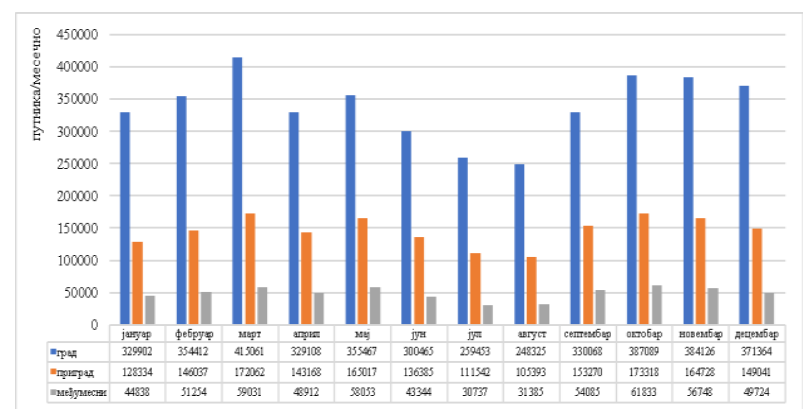

Slika 2. Broj prevezenih putnika po mesecima po podsistemima u 2018. godini

\subsection{Bruto transportni rad}

U transportno - poslovnom sistemu JP „SUBOTICA TRANS" u toku 2017. i 2018. se realizuje bruto transportni $\mathrm{rad}$ od 5.009.486 vozilo $\mathrm{km} \mathrm{i} 4.992 .361$ vozilo $\cdot \mathrm{km}$, respektivno.

Najveće učešće ima prigradski podsistem, koje iznosi $39,82 \%$ u 2017. i 40,03\% u 2018. godini.

\section{5. (MIKRO)ANALIZA LINIJE BROJ 6}

\subsection{Osnovne karakteristike linije broj 6}

Gradska linija broj 6 u Subotici je dijametralna linija koja povezuje dva periferna dela grada i prolazi kroz centar grada. Terminus A je stajalište koje nosi naziv Svarovski, dok terminus B nosi naziv Vikend Naselja. Oznake terminusa su određeni u skladu sa smerom koji je definisan u redu vožnje (zvaničan smer je Svarovski Vikend Naselja).

\subsection{Karakteristika putničkog toka na liniji}

Karakteristike putničkog toka na liniji su praćeni pomoću softvera "D-Logic". U sistemu mogu se prepoznati 4 tipa putnika u pogledu korišćenja putnih isprava. To su putnici sa mesečnim kartama (M), sa elektronskim novčanicima (E), sa vremenskim kartama (V) i sa papirnim kartama (P). Ulasci i izlasci putnika su evidentirani pomoću validatora.

\subsection{Dinamički elementi linije}

Poznato je da se dinamički elementi linije utvrđuju redom vožnje koji se menja periodično, u skladu sa promenama prevoznih zahteva na liniji.

Dinamički elementi predstavljaju značajne parametre kvaliteta JGPP-a. Razlikuju se osnovni (broj vozila na radu i vreme obrta) i izvedeni dinamički elementi (frekvencija i interval polazaka, prevozni kapacitet).

\section{SMERNICE U POGLEDU ODRŽIVOG RAZVOJA SISTEMA TRANSPORTA PUTNIKA U GRADOVIMA}

Budući da je od vitalnog značaja za ekonomski razvoj i normalno funkcionisanje društva, neophodno je podržavati mobilnost, ali u održivim i prihvatljivim okvirima.

Zbog toga se javlja i veoma je aktuelan pojam „održiva mobilnost", koji u suštini podrazumeva jednu buduću viziju društva, prema kojoj će 9 milijardi ljudi moći da živi dobro i u okvirima postojećih resursa planete.
U Akcionom planu za urbanu mobilnost objavljenom 2009. godine, Evropska komisija podržala je brže usvajanje Planova održive urbane mobilnosti (POUM) u Evropi pomoću materijala sa smernicama, promocijom razmene najboljih praksi, utvrđivanjem referentnih tačaka i podrškom edukativnih aktivnosti za profesionalce $u$ urbanoj mobilnosti.

\section{PREDLOG UNAPREĐENJA SISTEMA JAVNOG PREVOZA NA PODRUČJU SUBOTICE}

\subsection{Laki metro za gradsku liniju 6}

Nezavisni šinski sistem čine posebnu grupu tehničkih sredstava, objekata, infrastrukture, tehnologije i organizacije saobraćaja koji ostvaruje masovni prevoz putnika, po unapred određenoj trasi.

Karakteriše ga:

- spreg točak-šina,

- napajanje električnom energijom,

- integralnost procesa transporta,

- visok nivo prevozne sposobnosti,

- veliki kapacitet $\mathrm{i}$

- složena tehničko-tehnološka rešenja.

Laki metro predstavlja šinski prevoz na delimično izdvojenoj trasi od ostalog saobraćaja, u nivou, tunelima, vijaduktima ili izdvojenim čeličnim konstrukcijama.

Savremenom tehnologijom svaka nova faza razvoja ovog sistema smanjuje zavisnost od ostalog saobraćaja tako da ovaj delimično izdvojeni sistem javnog saobraćaja sve više poprima karakteristike metro sistema.

\subsection{Primena alternativnih goriva u preduzeću JP "Subotica-trans"}

Komprimirani prirodni plin je poznat na engleskom jeziku kao Compressed Natural Gas (CNG), na njemačkom Ergas (Komprimiert Erdgas). Compressed natural gasCNG je prirodni gas u gasovitom stanju kompresovan na pritisak od 220 bari pri temperaturi od $15^{\circ} \mathrm{C}$, što mu smanjuje zapreminu za oko 200 puta i koji se koristi za pogon motornih vozila kao alternativno gorivo.

Ekološka svest uz smanjenje troškova eksploatacije pri većem broju pređenih kilometara u odnosu na vozila $s$ konvencionalnim gorivima neki su od glavnih motiva koji su mnoge autobusne flote navele na odluku o uvođenju CNG vozila u njihove vozne parkove.

\section{ZAKLJUČAK}

Uvođenje lakog metroa možda nije opravdano sa ekonomskog i ekspolatacionog aspekta, ali moglo bi da bude opravdano sa aspekta tradicije preduzeća i atraktivnosti Palića.

Kada je u pitanju primena CNG plina kao pogonskog goriva u javnom gradskom prevozu, posebna pažnja se poklanja ekonomičnosti u cilju održivog razvoja javnog gradskog prevoza i zaštiti okruženja u urbanim sredinama, tj. ekološkom aspektu primene CNG plina kao pogonskog goriva. 


\section{LITERATURA}

[1] Univerzitet u Beogradu, Saobraćajni Fakultet "Unapređenje transportno-ekonomskih elemenata ugovora o pružanju komunalnih usluga u sistemu javnog transporta putnika u Subotici”, Beograd 2019.

[2] R. Banković "Organizacija i tehnologija javnog gradskog putničkog prevoza” Saobraćajni fakultet Beograd 1994.

\section{Kratka biografija:}

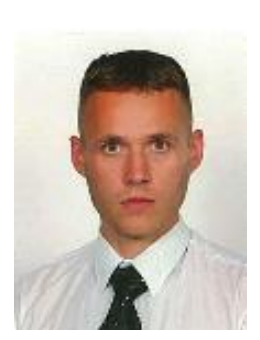

Čongor Erdedi, rođen je 1984. godine u Bečeju. Tehničku srednju školu „Ivan Sarić" završio je 2003. godine. Osnovne diplomske studije iz oblasti Saobraćaja i transporta upisao je 2015. godine $\mathrm{i}$ završio je 2019. godine na Fakultetu tehničkih nauka u Novom Sadu. 